\title{
In vitro anti-Candida effect of (S)-(-)-citronellal
}

\author{
Heloísa Mara Batista Fernandes de Oliveira ${ }^{1 *}$, Abrahão Alves de Oliveira Filho ${ }^{1}$, José Pinto de Siqueira Júnior ${ }^{1}$, \\ Edeltrudes Oliveira Lima ${ }^{1}$ \\ ${ }^{1}$ Program in Natural Products and Synthetic Bioactive, Federal University of Paraiba, Paraiba, Brazil. \\ ${ }^{2}$ Academic Unit Biological Sciences, Federal University of Campina Grande, Paraiba, Brazil.
}

\begin{tabular}{l} 
ARTICLE INFO \\
\hline Article history: \\
Received on: 05/10/2016 \\
Accepted on: 06/04/2017 \\
Available online: $30 / 11 / 2017$ \\
\hline Key words: \\
Monoterpene; Antifungal; \\
Candida tropicalis; Candida \\
albicans.
\end{tabular}

\section{INTRODUCTION}

Essential oils are natural plant products that have a large potential to replace the synthetic fungicides, due to their antifungal, antibacterial and insecticidal properties (Feng et al., 2007; Lee et al., 2008; Knaakand Fiuza, 2010). Essential oils are complex mixtures of volatile organic substances, consisting of oxygenated compounds and hydrocarbons such as monoterpenes and sesquiterpenes (Prabuseenivasan et al., 2006; Nerio et al., 2010). The terpenoids and phenolic compounds are responsible for the antimicrobial activity of essential oils, which accumulate on the membranes, with energy loss by microbial cells. Thus, the terpenoids that comprise essential oils forms a group of natural compounds with the great potential for developing products for disease control (Feng et al., 2007; Knaakand Fiuza, 2010).

\footnotetext{
* Corresponding Author

Heloísa Mara Batista Fernandes de Oliveira, Programin Natural Products and Synthetic Bioactive, Federal University of Paraiba, Paraiba-Brazil,email: heloisambf @ gmail.com
}

Citronellal is a monoterpene, found in more than 50 essential oils of various plant species. Citronellal is a constituent of several essential oils used to treat various pathological conditions in different parts of the world, such as South America and Asia (Nerio et al., 2010). Based on this information, this work is aimed to evaluate the antifungal potential of monoterpene (S)-(-)citronellal.

\section{MATERIALS AND METHODS}

The monoterpene (S)-(-)-citronellal was purchased from Sigma-Aldrich $^{\circledR}$ (SãoPaulo-SP). To achieve the pharmacological tests, the substance was solubilized in DMSO and diluted in distilled water. The concentration of DMSO was less than $0.1 \%$ $\mathrm{v} / \mathrm{v}$.

Determination of the minimum inhibitory concentration (MIC) The antifungal activity was performed on five selected strains of Candida albicans (ATCC 76485, LM62, LM106, LM 
108, LM 122) and five strains of Candida tropicalis (ATCC 13803, LM 06, LM 14, LM 31, LM 36). All the microorganism strains were obtained from the Laboratory of Mycology collection.

The antifungal activity was carried out according to the protocols described by Cleeland and Squires (1991), Hadacek and Greger (2000) and CSLI (2008).

The MICs of the monoterpene was determined against Candida strains by broth microdilution technique. Initially $100 \mu \mathrm{L}$ of Sabouraud dextrose broth was added to the wells of microdilution plate. Then, $100 \mu \mathrm{L}$ of the emulsion products, were dispensed in the wells of the first row. A ratio of two concentrations were obtained $1024 \mu \mathrm{g} / \mathrm{mL}$ to $2 \mu \mathrm{g} / \mathrm{mL}$, so that the first line of the plate was meet the highest concentration and last, the lowest concentration. Finally, $10 \mu \mathrm{L}$ of the inoculum was added to the cavities, where each plate column referred to a fungal strain, in particular.

In parallel, the feasibility control of the tested strains was carried out along with the sensitivity control, these strains to antifungal action considered standards in clinical use (Nistatin100 $\mathrm{UI} / \mathrm{mL}$ ). To verify the absence of interference of solvent (DMSO) in the results, a control was placed in the cavities $100 \mu \mathrm{L}$ of the double-concentrated broth, $100 \mu \mathrm{L}$ of DMSO and $10 \mu \mathrm{L}$ of the suspension was made.

The plates were sealed aseptically and incubated at $35^{\circ}$ C for $24-48$ hours. Testing was performed in duplicate and the result expressed by the arithmetic mean of the MIC's obtained in the two tests.

Determination of the minimum fungicide concentration (MFC)

A $20 \mu \mathrm{L}$ aliquot of each pit growth fungal (MIC, MIC x 2,

MIC x 4) was grown in a plate with Sabouraud Dextrose Agar. It was then incubated at $35-37{ }^{\circ} \mathrm{C}$ for 24 hours. The MFC was considered the lower concentration in Sabouraud Dextrose Agar planted where there were 3 lower growth units forming colonies (UFC) (Espinel-Ingroff et al., 2002).

\section{RESULTS AND DISCUSSION}

The evidence of microbial resistance is of great importance in treatment of candidiasis. Researches are going on for the search of new substances and combinations of drugs to treat microbial infections (Candido et al., 2000). The interest in plants with healing properties has grown considerably due to the prospect of isolating substances showing significant efficacy and lower rate of disadvantages, for example, the monoterpenes (Souza-Júnior et al., 2011).

The results of MIC (Minimum Inhibitory Concentration) and MFC (minimum fungicidal concentration) of monoterpene against the Candida albicans strains are shown in Table 1 and 2. The MIC and MFC of monoterpene against the Candida tropicalis are shown in Table 3 and 4 . The monoterpene presented $\mathrm{MIC}_{50}$ and $\mathrm{MFC}_{50}$ values of $256 \mu \mathrm{g} / \mathrm{mL}$, and $512 \mu \mathrm{g} / \mathrm{mL}$, respectively for both species of fungi.
Table 1: Antifungal activity for determination of the MIC of the (S)-(-)citronellal (SC) from Candida albicans strains.

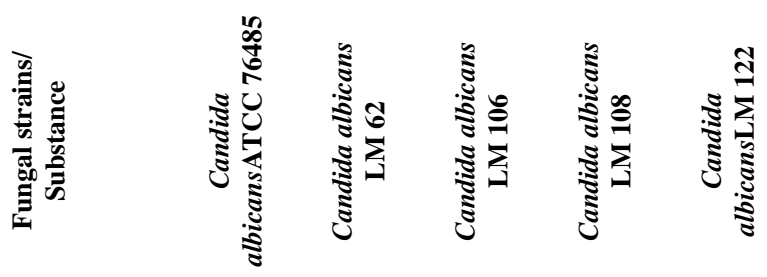

\begin{tabular}{cccccc}
\hline $\mathrm{SC}(1024 \mu \mathrm{g} / \mathrm{mL})$ & + & + & + & + & + \\
$\mathrm{SC}(512 \mu \mathrm{g} / \mathrm{mL})$ & + & + & + & + & - \\
$\mathrm{SC}(256 \mu \mathrm{g} / \mathrm{mL})$ & + & + & + & + & - \\
$\mathrm{SC}(128 \mu \mathrm{g} / \mathrm{mL})$ & - & - & - & - & - \\
$\mathrm{SC}(64 \mu \mathrm{g} / \mathrm{mL})$ & - & - & - & - & - \\
$\mathrm{SC}(32 \mu \mathrm{g} / \mathrm{mL})$ & - & - & - & - & - \\
$\mathrm{SC}(16 \mu \mathrm{g} / \mathrm{mL})$ & - & - & - & - & - \\
Negative control & - & - & - & - & - \\
Positive control & + & + & + & + & + \\
\hline
\end{tabular}

Table 2: Antifungal activity for determination of the MFC of the (S)-(-)citronellal(SC)from Candida albicans strains.

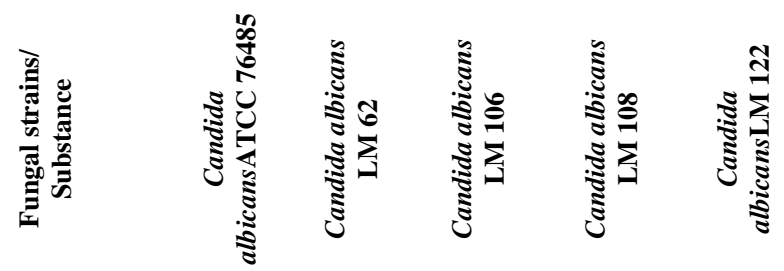

\begin{tabular}{cccccc}
\hline $\mathrm{SC}(1024 \mu \mathrm{g} / \mathrm{mL})$ & + & + & + & + & - \\
$\mathrm{SC}(512 \mu \mathrm{g} / \mathrm{mL})$ & + & + & - & + & - \\
$\mathrm{SC}(256 \mu \mathrm{g} / \mathrm{mL})$ & - & - & - & - & - \\
$\mathrm{SC}(128 \mu \mathrm{g} / \mathrm{mL})$ & - & - & - & - & - \\
$\mathrm{SC}(64 \mu \mathrm{g} / \mathrm{mL})$ & - & - & - & - & - \\
$\mathrm{SC}(32 \mu \mathrm{g} / \mathrm{mL})$ & - & - & - & - & - \\
$\mathrm{SC}(16 \mu \mathrm{g} / \mathrm{mL})$ & - & - & - & - & - \\
Negative control & - & - & - & - & - \\
Positive control & + & + & + & + & + \\
\hline
\end{tabular}

(-) No inhibition (+) inhibition.

Table 3: Antifungal activity for determination of the MIC of the (S)-(-)citronellal (SC) from Candida tropicalis strains.

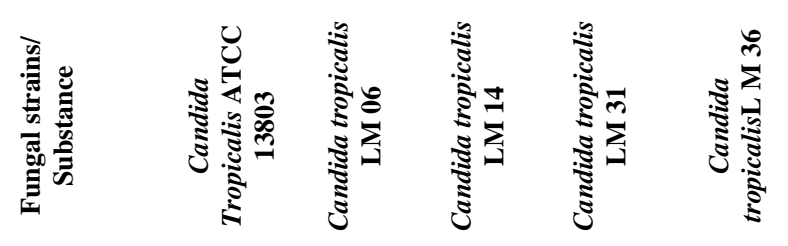

\begin{tabular}{llllll}
\hline $\mathrm{SC}(1024 \mu \mathrm{g} / \mathrm{mL})$ & + & + & + & + & + \\
$\mathrm{SC}(512 \mu \mathrm{g} / \mathrm{mL})$ & + & + & + & + & + \\
$\mathrm{SC}(256 \mu \mathrm{g} / \mathrm{mL})$ & + & + & + & - & - \\
$\mathrm{SC}(128 \mu \mathrm{g} / \mathrm{mL})$ & - & - & - & - & - \\
$\mathrm{SC}(64 \mu \mathrm{g} / \mathrm{mL})$ & - & - & - & - & - \\
$\mathrm{SC}(32 \mu \mathrm{g} / \mathrm{mL})$ & - & - & - & - & - \\
$\mathrm{SC}(16 \mu \mathrm{g} / \mathrm{mL})$ & - & - & - & - & - \\
Negative control & - & - & - & - & - \\
Positive control & + & + & + & + & + \\
\hline
\end{tabular}

(-) No inhibition (+) inhibition 
Table 4: Antifungal activity for determination of the MFC of the (S)-(-)citronellal (SC) from Candida tropicalis strains.
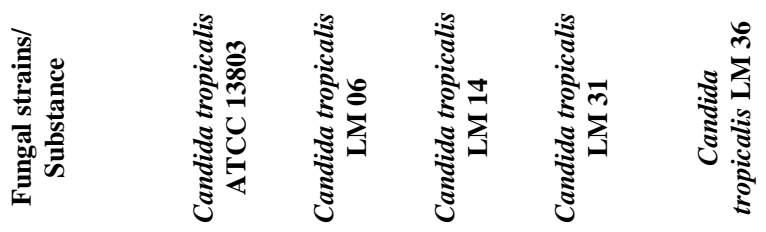

\begin{tabular}{llllll}
\hline $\mathrm{SC}(1024 \mu \mathrm{g} / \mathrm{mL})$ & + & + & + & + & + \\
$\mathrm{SC}(512 \mu \mathrm{g} / \mathrm{mL})$ & + & + & + & + & - \\
$\mathrm{SC}(256 \mu \mathrm{g} / \mathrm{mL})$ & + & - & - & - & - \\
$\mathrm{SC}(128 \mu \mathrm{g} / \mathrm{mL})$ & - & - & - & - & - \\
$\mathrm{SC}(64 \mu \mathrm{g} / \mathrm{mL})$ & - & - & - & - & - \\
$\mathrm{SC}(32 \mu \mathrm{g} / \mathrm{mL})$ & - & - & - & - & - \\
$\mathrm{SC}(16 \mu \mathrm{g} / \mathrm{mL})$ & - & - & - & - & - \\
Negative control & - & - & - & - & - \\
Positive control & + & + & + & + & + \\
\hline
\end{tabular}

(-) No inhibition (+) inhibition.

The results showed that monoterpene (S)-(-)-citronellal presents the strong effect against $C$. albicans and $C$. tropicalis strains with $\mathrm{MIC}_{50} 256 \mu \mathrm{g} / \mathrm{mL}$. These results are in agreement with the data obtained by Mirona et al. (2014) in their study using several monoterpenes against various strains of Candida. Analyzing the results of the MFC can be seen that the monoterpene have fungicide activity against both species of Candida, these results are also in agreement with Hafidh et al. (2011) when the ratios of MFC/MIC were 1 or 2 , indicating that the effect of the compound was fungicide in nature (and not fungistatic).

\section{CONCLUSION}

After analyzing the results of the monoterpene and comparison with other results already reported in the literature, it can be said that the (S)-(-)-citronellal is a promising compound to combat diseases caused by fungi of the genus Candida.

\section{Financial support and sponsorship: None.}

Conflict of Interests: There are no conflicts of interest.

\section{REFERENCES}

Candido RC, Azevedo RVP, Komesu MC. Enzimotipagem de espécies do gênero Candida isoladas da cavidade bucal. Rev Soc Bras Med Trop, 2000; 33 (5):437-42.

Cleeland R, Squires E. Evalution of new antimicrobials in vitro and in experimental animal infections. In: Lorian, V. M. D. Antibiotic Lab Med. New York: Willians \& Wilkins, 1991; 739-788.

CLSI. Reference method for broth dilution antifungal susceptibility testing of yeasts. CLSI document M27-A3, 2008; 28(14); 10.
Espinel-Ingroff A, Chaturvedi V, Fothergill A, Rinaldi MG. Optimal testing conditions for determining MICs and minimum fungicidal concentrations of new and established antifungal agents for uncommon molds: NCCLS collaborative study. J Clin Microbiol, 2002;40(10): 37763781 .

Feng W, Zheng X. Essential oils to control Alternaria alternate in vitro and in vivo. Food Control, 2007; 18: 1126-1130.

Hadacek F, Greger H. Testing of antifungal natural products: methodologies, comparatibility of results and assay choice. Phytoch Anal, 2000; 11: 137-147.

Hafidh RR, Abdulamir AS, Vern LS, Bakar FA, Abas F, Jahanshiri F, Sekawi Z. Inhibition of growth of highly resistant bacterial and fungal pathogens by a natural product. Open Microbiol J, 2011; 5, 96106.

Knaak N, Fiuza LM. Potencial of essential plant oils to control insects and microorganisms. Neotropical Biology and Conservation, 2010; 5(2): 120-132

Lee YS, Kim J, Shin SC, Lee SG,Parket IK. Antifungal activity of Myrtaceaeess ential oils and their components against three phytopathogenic fungi. FlavourFrag J, 2008; 23: 23-28.

Matos FJA. Introdução a fitoquímica experimental. Ed. UFC, Fortaleza; $1997.141 \mathrm{p}$.

Mirona D, Battistia F, Silva FK, Lana AD, Pippi B, Casanova B, Gnoattoc S, Fuentefriab A, Mayorgad P, Schapovala EES. Antifungal activity and mechanism of action of monoterpenes against dermatophytes and yeasts. Rev Bras Farmacogn, 2014; 24(6): 660-667.

Nerio LS, Olivero-Verbel J, Stashenko E. Repellent activity of essential oils: a review. Bioresource Technology, 2010; 101: 372-378.

Park IK, Choi KS, Kim DH, Choi IH, Kim LS, Bak WC, Choi JW, Shin SC. Fumigant activity of plant essential oils and components from horse radish (Armoracia rusticana), anise (Pinpinella anisum) andgarlic (Allium sativum) oils against Lycoriellaingenue (Diptera: Sciaridae). Pest Manag Sci, 2006; 62: 723-728.

Prabuseenivasan S, Jayakumar M, Ignacimuthu S. In vitro antibacterial activity of some plant essentialoils. BMC Complement Altern Med, 2006; 6:39.

Sartoratto A, Machado ALM, Delarmelina C, Figueira GM, Duarte MCT, Rehder VLG. Composition and antimicrobial activity of essential oils from aromatic plants used in Brazil. Braz J Microbiol, 2004; 35: $275-280$.

Satish S, Mohana DC, Raghavendra MP, Raveeshaet KA. Antifungal activity of some plant extracts against important seed borne pathogens of Aspergillus sp. J Agric Technol, 2007; 3(1): 109-119.

Souza-Júnior UP, Pereira JV, Pereira MSV, Costa MRM, Antunnes RMP. Atividade Antifúngica In vitro do extrato de Uncaria tomentosa L sobre cepas do gênero Candida. Pesq Bras Odontoped ClinIntegr, 2011; 11(4):477-80.

How to cite this article:

deOliveira HMBF, Filho AAO, Lima EO, Júnior JPS. In vitro antiCandida effect of (S)-(-)-citronellal. J App Pharm Sci, 2017; 7 (11): 177-179. 